\title{
Income Distribution in Turkey during the Global Financial Crisis
}

\author{
Sinem Sefil-Tansever ${ }^{1, *}$ \\ ${ }^{1}$ Deparment of Economics, Istanbul Commerce University, Istanbul, Turkey \\ *Correspondence: Department of Economics, Istanbul Commerce University, Istanbul, \\ Turkey. E-mail: ssefil@ticaret.edu.tr
}

Received: August 15, 2017 Accepted: August 26, 2017 Published: September 8, 2017

doi: 10.5296/rae.v9i3.11709 URL: https://doi.org/10.5296/rae.v9i3.11709

\begin{abstract}
The aim of this study is to examine mechanism responsible for the behavior of the income and earning inequality in Turkey during the global financial crisis based on data from the 2006 to 2014 Income and Living Conditions Survey. Gini decomposition by income source is employed in order to provide an analysis of the contribution of the various income sources to the evolution of income inequality and to assess the impact of a marginal percentage change in the income from a particular source on income inequality. For examining the contributions of specific variables (education, position in occupation, economic sector) to the interpretation of labor earnings inequality in terms of their gross and marginal contribution, we use static decomposition of Theil T index.
\end{abstract}

Keywords: Income Inequality, Decomposition, Gini Coefficient, Theil-T Index 


\section{Introduction}

Although the economic consequences of the global financial crisis can be assessed from several perspectives, one of the most discussed issues is that of income distribution of households. However the literature concerning the quantitative levels and asymmetric effects (describing the fact that different groups can be affected differently) of income distribution costs created by financial crises in developing countries is very limited. In particular, the number of detailed, multi-faceted and comprehensive studies taking into account the specific conditions of individual countries and the changes in welfare of all the agents in the economic system following a financial crisis, is highly limited.

The direction of the causal relationship between financial crisis and household income inequality has been a controversial issue. Conventionally, the aftermath of financial crises have been associated to widening income inequality. On the other hand, it could be argued that crises led to improvements in inequality reflecting the drastic capital losses of the top decile as a result of the financial crisis in that their income was affected severely relative to income of those at the bottom decile. The severe distributional impacts of the global financial crisis have been studied extensively in advanced countries (Mishel and Gee, 2012; Mishel, 2012; Dufour and Orhangazi, 2014; Saez, 2015) also in developing and low income countries (Cord et al., 2017; Otker-Robe and Podpiera, 2013; Brinkman et al., 2010; Arieff et al., 2011). Another line of research has been focused on the positive impacts of the transfers and benefits to the poor in the countries that recovered fastly from harmful distributional effect of the global financial crisis (Agnello and Sousa, 2014; Woo et al., 2013; Ball et al., 2013; Brandolini et al., 2013; Jovanovic, 2014). Also, De Beer (2012) presented that a few European Union (EU) countries experienced decreasing inequality following the global financial crisis.

Income inequality has long been a crucial issue for Turkey. Although, Turkey's income inequality has been slightly lower relative to those of in the same class of the per capita income level with Turkey (such as Mexico, China, Brazil) in the middle-high income group, Turkey has been ranked among the top three countries in the Organization for Economic Cooperation and Development (OECD) region in terms of income inequality and ratio of top $\% 10$ decile to bottom $\% 10$ decile.

Despite the economic boom of the Turkish economy from 2002 to 2008, which witnessed relatively low inflation and high growth, the economy has more recently been severely affected by the global financial crisis of 2008-2009 due to its large current account deficit, strong dependency on construction activity, and consumer demand. Therefore, the household and personal income distribution consequences of the crisis need careful examination.

The aim of this study is investigating the determining factors of income distribution in terms of income and earning inequality in Turkey by i) decomposing the Gini index by source of income in order to present the contribution of the several source of incomes to the changes in income inequality in terms of their gross and marginal contributions ii) examining the contributions of specific variables (education, position in occupation, economic sector) to the interpretation of labor earnings inequality in terms of their gross and marginal contribution 
through static decomposition of Theil T index.

Section 2 briefly reviews the literature in this field, while section 3 summarizes the data and methodology used in the study. Section 4 provides the findings and section 5 presents brief conclusions.

\section{Literature Survey}

The literature on the decomposition of the Gini coefficient by sources of income was established by Rao (1969), Fei et al. (1978), Pyatt et al. (1980) and Sharrocks (1982). Developing the Sharrocks' (1982) decomposition, Lerman and Yitzhaki (1985) proposed a decomposition of Gini coefficient by income source. Based on Lerman and Yitzhaki's (1985) approach, Stark et al (1986) showed the derivation of the effect of a marginal change in an source of income on the total inequality. Other methodologies of Gini decomposition by income source such as Silber (1993), Podder and Chatterjee (2002), Araar (2006), Araar and Duclos (2008) proposed also have been used in literature.

There are only a limited number of studies addressing impact of various income sources to inequality in Turkey. Silber and Özmucur (2000) examined the impact of various income sources to total income inequality by using Silber's (1993) decomposition and they found that; in 1994, contribution of income from a primary job to total inequality is relatively higher in urban areas while contribution of income from secondary job is higher in rural areas in Turkey. Başlevent (2010) investigated the contribution of labor market earnings, non-wage income and imputed rents to total income inequality using the Jenkin's (1995) extension to Sharrocks's (1982) decomposition with 1994 Household Income Distribution Survey (HIDS) and the 2003 and 2008 Household Budget Surveys (HBS) provided by the Turkish Statistical Institute. He found that, female earnings have a decreasing impact on household inequality and contribution of non-labor income inequality decreases from 1994 to 2008. Çetin and Gül (2013) employed Sharrocks's (1982) decomposition method to Household Budget Survey data of Turkish Statistical Institute between 2002-2009 and they showed that, interest income has the relatively highest contribution to income inequality and contributions of the profit, rent and interest incomes to income inequality are significantly higher than the contributions of transfer and wage incomes. Arslan (2014) showed that, although earning income is responsible for an important share in total inequality; by time, share of earnings income decreases in inequality in favor of non-earnings income as an income source by employing Gini decomposition of Lerman and Yitzhaki (1985) with Household Budget Surveys data of 2002 and 2011. Başveren (2014) used Shorrocks 's (1982) decomposition to investigate redistributive effect of social transfers on income inequality in Turkey by using data from 2013 Turkish Income and Living Survey and pointed out the inadequacy of data to measure the social transfers correctly.

Interpretation of the Theil-T index decomposition in terms of gross and marginal contributions of different groups to total inequality has been subjected to some studies such as Psacharopoulos et al. (1993) Acevedo and Salinas (2000), Camargo and Neri (2002) which 
all pointed the significant marginal and gross contribution of education to inequality.

By using the Static decomposition of Theil-T index, Psacharopoulos et al. (1993) found that gross contribution of education has a relatively higher gross contribution to inequality in Latin America and the Caribbean countries. Also, education has the largest marginal contribution to inequality among these countries except Bolivia and Uruguay in 1986. By employing Gini decomposition of Lerman and Yitzhaki (1985) Acevedo and Salinas (2000) showed that, in Mexico, labor earnings is a growing and significant source of income inequality. Also their results from the static decomposition analysis of Theil-T index show that, among the three variable set that consists of education, position in occupation and economic sector, education makes the greatest contribution to earning inequality both in terms of marginal and gross level. They also presented that, after the financial crisis Mexico experienced in 1995, the gross and marginal contribution of education decreased significantly. Using Mexican data between 1976 and 1997, Neri and Camargo (2002) found that working classes and years of schooling explains most of the total inequality with and increasing trend in terms of their gross contributions while marginal contribution of years schooling has the largest impact on the inequality.

In Turkey case, although there are studies that used decomposition of Theil-T index into between and within components, none of them expressed this analysis with gross and marginal contribution elements. Elveren and Galbraith (2009) examined the pay inequality in Turkish manufacturing sector between 1980 and 2001. Using Annual Manufacturing Industry Statistics (AMIS) collected by the Turkish Statistical Institute, they decomposed the Theil-T statistic by sub-sector, province, East-West distinction and geographic region for public and private sectors. They found that while pay inequality between regions does not change, in the late 1980s, pay inequality increases in the private sector between East and West, between provinces, and between sub-sectors. Şenergin (2010) decomposed Theil-T index into between and within components by using Turkish Household Budget Survey data of 2008 and showed that the disturbing effect on income distribution is at the highest level in primary school. Taştan and Akar (2013) examined the pay inequality in Turkey using Theil's T statistic calculated from employment and wage data of Turkish Statistical In $\neg$ stitute for the 1992-2010. By focusing on regions and sector subgroups, they found that, pay inequality between sectors rises during recession and crisis periods (1994, 2001 and 2008).

\section{Data and Methodology}

The analysis in this study is based on data from the 2006 to 2014 Income and Living Conditions Survey (SILC) of the Turkey which have been collected annually by the Turkish Statistical Institute (TurkStat) since 2006. Data has been collected using a survey formed by panel survey method with the aim of supplying comparable measurements on household and personal income distribution, standard of living, poverty and social exclusion as part of the studies regarding adaptation to European Union (EU). The topics of education, housing, ownership of assets, economic situation, health status, income status, labor status, demography and social exclusion are covered in the survey to calculate indicators for income, 
living conditions, poverty and social exclusion. Sample unit is determined as the household. Although sample size is determined as approximately 13000 household at the beginning, it varies from year to year since the survey is a panel application.

In order to estimate the contribution of the several source of incomes on income inequality, Gini index decomposition by income sources is employed to present the contribution of the several source of incomes. By following Lerman and Yitzhaki (I985), Gini index (G) for the overall income distribution can be expressed as a function of the covariance between income and its cumulative distribution, that is,

$$
\mathrm{G}=\frac{(2 \operatorname{cov}[\mathrm{Y}, \mathrm{F}(\mathrm{Y})])}{\mu},
$$

where $\mathrm{Y}$ is the per capita income distribution $(\mathrm{Y}=(\mathrm{y} 1, \ldots \ldots . \mathrm{yn})$ where $\mathrm{yn}$ denotes the individual $i$ 's level of per capital income $(i=1, \ldots n)), \mu$ is the mean of capita income, $F(Y)$ is the cumulative distribution of overall per capita income in the sample i.e $F(Y)=$ $[\mathrm{f}(\mathrm{y} 1), \ldots . . . \mathrm{f}(\mathrm{yn})]$ where $\mathrm{f}(\mathrm{yi})$ corresponds to rank of yi divided by the number of observations (n) (Note 1). (Acevedo, Salinas, 2000, 23).

Utilizing the properties of the covariance, equation (1) can be represented as an expression that captures the each $\mathrm{K}$ income components' contribution to income inequality.

$$
\mathrm{G}=\sum_{k=1}^{K}\left[\frac{\mu_{k}}{\mu} * \frac{\left(2 \operatorname{cov}\left[y_{k}, F(Y)\right]\right)}{\mu_{k}} * \frac{\operatorname{cov}\left[y_{k}, F(Y)\right]}{\operatorname{cov}\left[y_{k}, F\left(Y_{k}\right]\right.}\right]=\sum_{k=1}^{K} S_{k} G_{k} R_{k}
$$

where $S_{k}$ is the income source k's share of total group income $\left(S_{k}=\mu_{k} / \mu\right) ; G_{k}$ is the Gini coefficient of income source $\mathrm{k}$ within the group, $\mathrm{R}_{\mathrm{k}}$ is the Gini correlation of income from component $\mathrm{k}$ with total income distribution(Note 2) (Stark at all, 1986, 21).

The larger the product of $S_{k}, G_{k}$ and $R_{k}$, the greater the contribution of income component $k$ to overall income inequality. Nevertheless, it must be pointed that while $R_{k}$ is defined on the interval $(-1,1], G_{k}$ and $S_{k}$ are always less than one and positive. When $R_{k}$ falls below zero, income component $\mathrm{k}$ is negatively correlated with overall income and therefore lowers the Gini coefficient (Leibbrandt et al, 2000, 85).

Using this formulation, the effect of a minor percentage change in any income source on Gini coefficient, i.e. the impact of various income components on income inequality can be calculated. Under the assumption of there is an exogenous increase in overall income stemming from income component $j$, by a factor $\sigma_{j}\left(\left(y_{i j}\left(\sigma_{j}\right)=\left(1+\sigma_{j}\right) y_{i j}\right)\right.$ for $\left.\left.i=1, \ldots . n\right)\right)$ income distribution of component $\mathrm{j}$ becomes $\mathrm{Y}_{\mathrm{j}}=\left(\left(1+\sigma_{\mathrm{j}}\right) \mathrm{y}_{\mathrm{ij}}, \ldots\left(1+\sigma_{\mathrm{j}}\right) \mathrm{y}_{\mathrm{nj}}\right)$. As Stark et al. (1986) showed, the derivative of the Gini index with respect to a change in income component $\mathrm{j}$ is:

$$
\frac{\partial G}{\partial \sigma_{j}}=S_{j}\left(R_{j} G_{j}-G\right)
$$




\section{Macrothink}

In case of this derivative is negative, income inequality will decrease by the marginal increase in income component $j$. This will occur when income from source $j$ has zero or negative correlation with total income $\left(-1 \leq \mathrm{R}_{\mathrm{j}} \leq 0\right)$ or when there is a positive correlation between income from component $j$ and total income $\left(\left(R_{j}>0\right)\right.$ and $\left.R_{j} G_{j}<G\right)$.

Dividing equation (4) by $\mathrm{G}$, it is obtained that:

$$
\frac{\partial G}{\partial \sigma_{j}} \frac{1}{G}=\frac{S_{j} R_{j} G_{j}}{G}-S_{j}
$$

Equation (4) implies that the marginal percentage change in income inequality (as calculated through the Gini coefficient) stemming from a small percentage change in income from source $\mathrm{j}$ is equal to source $\mathrm{j}$ 's share in total inequality minus source $\mathrm{j}$ 's share in total income.

To put it another way, this percentage change can be stated as $N_{j}=R_{j} G_{j} / G$ which is theGini elasticity.

$$
\frac{\partial \mathrm{G}}{\partial \sigma_{\mathrm{j}}} \frac{1}{\mathrm{G}}=\mathrm{S}_{\mathrm{j}}\left(\mathrm{N}_{\mathrm{j}}-1\right)
$$

Therefore, a percentage increase in the income from income component $j$ with an elasticity of Gini $\mathrm{N}_{\mathrm{j}}$ larger (smaller) than one will increase (decrease) the inequality. The lower the Gini elasticity implies larger the re-distributive impact (Acevedo, Salinas, 2000, 6-7).

In order to investigate the factors and mechanisms driving inequality, static and dynamic decomposition of Theil $\mathrm{T}$ index which is sensitive to changes at the top and bottom tail of the income distribution is employed. Following the mathematical notation of Acevedo and Salinas (2000), Theil $\mathrm{T}$ is expressed as follows:

$$
\mathrm{T}=\left(\frac{1}{\mathrm{n}}\right) \sum_{\mathrm{i}=1}^{\mathrm{n}}\left(\frac{\mathrm{Y}_{\mathrm{i}}}{\overline{\mathrm{Y}}}\right) \ln \left(\frac{\mathrm{Y}_{\mathrm{i}}}{\overline{\mathrm{Y}}}\right)
$$

where $\mathrm{n}$ is the population size, $\overline{\mathrm{Y}}$ is the average income and $\mathrm{Yi}$ is the ith individual's income. Assuming $\mathrm{n}$ is divided into $\mathrm{G}$ groups with $\mathrm{ng}$ observations, equation (6) can be expressed as

$$
\mathrm{T}=\sum_{\mathrm{g}=1}^{\mathrm{G}}\left(\frac{1}{\mathrm{n}}\right) \sum_{\mathrm{i}=1}^{\mathrm{n}_{\mathrm{g}}}\left(\frac{\mathrm{Y}_{\mathrm{ig}}}{\overline{\mathrm{Y}}}\right) \ln \left(\frac{\mathrm{Y}_{\mathrm{ig}}}{\overline{\mathrm{Y}}}\right)
$$

where $\mathrm{Y}_{\mathrm{ig}}$ is the income of the $\mathrm{i}_{\mathrm{it}}$ individual in the $\mathrm{g}_{\mathrm{it}}$ subgroup of the population. Defining

$$
\beta_{\mathrm{g}}=\mathrm{n} \mathrm{g} / \mathrm{n} \text { and } \mathrm{Z}_{\mathrm{g}}=\overline{\mathrm{Y}_{\mathrm{g}}} / \mathrm{k}
$$

where $\mathrm{k}$ is a reference income and $\overline{\mathrm{Y}}_{\mathrm{g}}$ is the average income of the gth group,, $\mathrm{T}$ can be written as 


$$
\mathrm{T}=\left(\frac{1}{\mathrm{k}}\right) \sum_{\mathrm{g}=1}^{\mathrm{G}} \mathrm{B}_{\mathrm{g}} \mathrm{Z}_{\mathrm{g}} \ln \mathrm{Z}_{\mathrm{g}}-\operatorname{lnk}+\left(\frac{1}{\mathrm{k}}\right) \sum_{\mathrm{g}=1}^{\mathrm{G}} \beta_{\mathrm{g}} \mathrm{Z}_{\mathrm{g}} \mathrm{T}_{\mathrm{g}}
$$

Where $T_{g}$ is the Theil $T$ index of the $g_{i t}$ subgroup and $k=\sum \beta_{g} Z_{g}$. The first two terms on the right hand side of equation 8 stand for between group inequality while the third term denotes within group inequality. Assigning the mean income as the reference income $\left(\mathrm{Z}_{\mathrm{g}}=\alpha_{\mathrm{g}}=\overline{\mathrm{Y}_{\mathrm{g}}} / \overline{\mathrm{Y}}\right)$, equation 8 can be defined as,

$$
\mathrm{T}=\sum_{\mathrm{g}=1}^{\mathrm{G}} \alpha_{\mathrm{g}} \beta_{\mathrm{g}} \ln \alpha_{\mathrm{g}}+\sum_{\mathrm{g}=1}^{\mathrm{G}} \alpha_{\mathrm{g}} \beta_{\mathrm{g}} \mathrm{T}_{\mathrm{g}}
$$

where first term is between group inequality and the second term is within group inequality. Decomposing the Theil $\mathrm{T}$ index into between and within group components by using subgroups is defined as "static decomposition of Theil T index".

\section{Findings}

The general results regarding the evolution of income inequality in Turkey can be seen in Table 1. Gini coefficient and generalized entropy (GE) indexes cover the period of 2006 to 2014. Four values of generalized entropy sensitivity parameters $(-1,0,1,2)$ were employed in the calculations. A more positive (negative) sensitivity parameter implies a GE measure that is more sensitive to income differences at the top (bottom) of the distribution. Disposable income was adjusted using the national equivalence scale based on a parameter equivalence scale form.(Note 3)

Table 1. Economic Inequality Measures by Years

\begin{tabular}{cccccccccc}
\hline Inequality Measure* & $\mathbf{2 0 0 6}$ & $\mathbf{2 0 0 7}$ & $\mathbf{2 0 0 8}$ & $\mathbf{2 0 0 9}$ & $\mathbf{2 0 1 0}$ & $\mathbf{2 0 1 1}$ & $\mathbf{2 0 1 2}$ & $\mathbf{2 0 1 3}$ & $\mathbf{2 0 1 4}$ \\
\hline GE(-1) & 0.476 & 0.389 & 0.392 & 0.438 & 0.390 & 0.394 & 0.403 & 0.438 & 0.347 \\
GE $(0)$ & 0.338 & 0.302 & 0.297 & 0.313 & 0.297 & 0.298 & 0.292 & 0.283 & 0.267 \\
GE $(1)$ & 0.357 & 0.337 & 0.324 & 0.340 & 0.331 & 0.323 & 0.314 & 0.309 & 0.285 \\
GE $(2)$ & 0.575 & 0.605 & 0.555 & 0.582 & 0.647 & 0.545 & 0.524 & 0.516 & 0.433 \\
Gini & 0.439 & 0.418 & 0.415 & 0.424 & 0.415 & 0.415 & 0.410 & 0.406 & 0.396 \\
\hline
\end{tabular}

Source: Own calculations based on SILC Data

*Based on total income equalized by National Equivalence Scale (2002).

All inequality measures exhibit a decrease from 2006 to 2014. However, it can be seen that this overall decrease in income inequality was interrupted by the global financial crisis period. The top-sensitive GE (2) indices begin to increase by 2009, and then decreases in 2011. All 
the other GE indices and Gini coefficients increase by 2008, then show a slight decrease by 2010. Bottom-sensitive GE (-1) indices increased by almost 5\% from 2008 to 2009. Following these fluctuations, all inequality measures decreased below their 2007 level in 2014.

Table 2. Lorenz Curves for Total Equalized Income* (accumulated income share)

\begin{tabular}{|c|c|c|c|c|c|c|c|c|c|}
\hline Accumulated Share & 2006 & 2007 & 2008 & 2009 & 2010 & 2011 & 2012 & 2013 & 2014 \\
\hline \multirow{2}{*}{10} & 1.80 & 2.12 & 2.16 & 2.05 & 2.17 & 2.16 & 2.18 & 2.28 & 2.32 \\
\hline & $(0.009)$ & $(0.011)$ & $(0.009)$ & (0.009) & $(0.009)$ & $(0.008)$ & $(0.007)$ & $(0.008)$ & $(0.007)$ \\
\hline \multirow{2}{*}{20} & 4.97 & 5.61 & 5.68 & 5.48 & 5.75 & 5.77 & 5.80 & 5.97 & 6.04 \\
\hline & (0.009) & $(0.011)$ & (0.009) & $(0.009)$ & (0.009) & $(0.008)$ & $(0.007)$ & (0.007) & $(0.007)$ \\
\hline \multirow{2}{*}{30} & 9.23 & 10.19 & 10.28 & 10.03 & 10.45 & 10.44 & 10.49 & 10.69 & 10.81 \\
\hline & (0.009) & $(0.010)$ & (0.009) & (0.009) & $(0.009)$ & $(0.007)$ & $(0.007)$ & $(0.007)$ & $(0.007)$ \\
\hline \multirow{2}{*}{40} & 14.59 & 15.80 & 15.96 & 15.66 & 16.21 & 16.13 & 16.22 & 16.45 & 16.61 \\
\hline & $(0.008)$ & $(0.010)$ & (0.009) & $(0.008)$ & $(0.009)$ & $(0.007)$ & $(0.007)$ & $(0.007)$ & $(0.006)$ \\
\hline \multirow{2}{*}{50} & 21.12 & 22.49 & 22.76 & 22.40 & 23.07 & 22.91 & 23.07 & 23.27 & 23.46 \\
\hline & $(0.008)$ & $(0.010)$ & $(0.008)$ & (0.008) & $(0.009)$ & $(0.007)$ & $(0.007)$ & $(0.007)$ & $(0.006)$ \\
\hline \multirow{2}{*}{60} & 29.02 & 30.39 & 30.87 & 30.38 & 31.12 & 30.96 & 31.19 & 31.27 & 31.56 \\
\hline & $(0.008)$ & $(0.010)$ & $(0.008)$ & $(0.008)$ & $(0.008)$ & $(0.007)$ & $(0.007)$ & $(0.007)$ & $(0.006)$ \\
\hline \multirow{2}{*}{70} & 38.59 & 39.82 & 40.60 & 39.89 & 40.80 & 40.55 & 40.77 & 40.76 & 41.22 \\
\hline & $(0.007)$ & (0.009) & $(0.008)$ & $(0.007)$ & $(0.008)$ & $(0.007)$ & $(0.006)$ & $(0.006)$ & $(0.006)$ \\
\hline \multirow{2}{*}{80} & 50.53 & 51.33 & 52.67 & 51.55 & 52.57 & 52.29 & 52.49 & 52.29 & 53.03 \\
\hline & $(0.007)$ & $(0.009)$ & $(0.007)$ & (0.007) & $(0.008)$ & $(0.006)$ & $(0.006)$ & $(0.006)$ & $(0.005)$ \\
\hline \multirow{2}{*}{90} & 66.40 & 66.54 & 68.41 & 67.29 & 68.11 & 67.96 & 68.16 & 67.75 & 68.90 \\
\hline & $(0.006)$ & $(0.008)$ & $(0.006)$ & $(0.006)$ & $(0.007)$ & $(0.005)$ & $(0.005)$ & $(0.005)$ & $(0.004)$ \\
\hline \multirow{2}{*}{92} & 70.46 & 70.34 & 72.33 & 71.26 & 71.99 & 71.91 & 72.11 & 71.73 & 72.92 \\
\hline & $(0.007)$ & $(0.010)$ & $(0.008)$ & $(0.008)$ & (0.008) & $(0.007)$ & $(0.006)$ & $(0.006)$ & $(0.006)$ \\
\hline \multirow{2}{*}{94} & 75.15 & 74.67 & 76.74 & 75.76 & 76.32 & 76.32 & 76.51 & 76.20 & 77.41 \\
\hline & $(0.007)$ & $(0.009)$ & $(0.007)$ & $(0.007)$ & $(0.008)$ & $(0.006)$ & $(0.006)$ & $(0.006)$ & $(0.005)$ \\
\hline \multirow{2}{*}{96} & 80.59 & 79.81 & 81.72 & 81.02 & 81.35 & 81.41 & 81.62 & 81.33 & 82.56 \\
\hline & $(0.006)$ & (0.009) & $(0.007)$ & 0.007 & 0.008 & 0.006 & $(0.006)$ & $(0.006)$ & $(0.005)$ \\
\hline \multirow{2}{*}{98} & 87.56 & 86.62 & 88.00 & 87.64 & 87.68 & 87.83 & 88.02 & 87.76 & 88.94 \\
\hline & $(0.005)$ & $(0.007)$ & $(0.006)$ & $(0.006)$ & $(0.007)$ & $(0.005)$ & $(0.005)$ & $(0.005)$ & $(0.004)$ \\
\hline 100 & 100.00 & 100.00 & 100.00 & 100.00 & 100.00 & 100.00 & 100.00 & 100.00 & 100.00 \\
\hline Bottom $20 \%$ & 5 & 5.6 & 5.7 & 5.5 & 5.8 & 5.8 & 5.8 & 5.9 & 6 \\
\hline Middle $40 \%$ & 24 & 24.8 & 25.2 & 24.9 & 25.4 & 25.2 & 25.4 & 25.3 & 25.5 \\
\hline Middle high $30 \%$ & 37.4 & 36.2 & 37.5 & 36.9 & 37 & 37 & 37 & 36.5 & 37.4 \\
\hline Top $10 \%$ & 33.6 & 33.5 & 31.6 & 32.7 & 31.9 & 32 & 31.8 & 32.3 & 31.1 \\
\hline
\end{tabular}

Source: Own calculations based on SILC Data *Based on National Equivalence Scale (2002). Standard errors are in the brackets 
In order to investigate the effects of the crisis period on different income shares, Lorenz curves for total equalized income were estimated (see Table 2). It can be seen that, over the analysis period of 2006 to 2014, the richest $10 \%$ of the country lost 2.5 percentage points of their income share, while the poorest $20 \%$ and middle $40 \%$ increased theirs by 1 and 1.5 percentage points, respectively. Therefore, despite of the decrease in income inequality, income transfer to both the bottom and middle classes was not significant.

Between 2008 and 2009, there was a slight decrease in the income shares of the bottom, middle, and middle-high income groups. After a slight increase in 2010, the bottom and middle-high income groups sustained their income levels and slightly increased it in 2014, while the middle income group lost 0.2 percentage points of their income share in 2011 and recovered it in 2014. On the other hand, the income share of top $10 \%$ and the top $1 \%$ income groups followed a different pattern during the crisis and afterward.

Following a 1.9 percentage point decrease in 2008, the top $10 \%$ income group increased its share by 1.1 percentage points in 2009 . After this small recovery, the income share of this group worsened by a 0.8 decrease in 2010, which was followed by a minor increase in 2011 and a 0.9 decrease in 2014. Therefore, while low and middle income groups received income shares higher than their pre-crisis levels in 2014 and middle-high income groups recovered to their pre-crisis level, richest stratum could not reach its pre-crisis income share level.

In order to investigate the impact of various income components on income inequality, Gini index decomposition by source of income (introduced by Lerman and Yitzhaki (1985)) was employed. In Table 3, the results of the Gini decomposition analysis are displayed. The results show that total labor earnings make up the largest share of total income in each year save for 2008. Total labor earnings, entrepreneur income, and pensions and survivor benefits together constitute more than $60 \%$ of total income. Financial income follows these as the forth-largest component.

The results show that total labor earnings make up the largest share of total income in each year save for 2008. Total labor earnings, entrepreneur income, and pensions and survivor benefits together constitute more than $60 \%$ of total income. Rental income follows these as the forth-largest component. The decomposition results show total labor earnings and entrepreneur income to be the most significant sources of income inequality. After a significant decrease in 2007 , the contribution of entrepreneur income to inequality increased by $37.7 \%$ in 2008 , decreased gradually from 2008 to 2010 . Following an increased in 2011, it gradually decreased from 2012 to 2014.

The contribution of total labor earnings to inequality moved in the opposite direction over the period of analysis, increasing gradually from 2008 to 2010, and then showing a slight decrease in 2011. Then, it gradually increased from 2012 to 2014.Rental income increased its contribution to inequality in 2007 by $27 \%$, slightly decreased in 2008, recovered its contribution level in 2009, and then decreased to below its 2006 level in 2014. In 2007 and 2010, social transfers contributed negatively to income inequality in a similar manner to inter-household transfers in 2007, 2008, 2010, 2012 and 2013. 
Table 3. Decomposition of Gini by Income Source, Share in Overall Gini

\begin{tabular}{|c|c|c|c|c|c|c|c|c|c|}
\hline & $\begin{array}{c}\text { Total } \\
\text { Labor } \\
\text { Earning }\end{array}$ & $\begin{array}{c}\text { Entrepreneur } \\
\text { income }\end{array}$ & $\begin{array}{c}\text { Financial } \\
\text { income }\end{array}$ & $\begin{array}{l}\text { Rental } \\
\text { Income }\end{array}$ & $\begin{array}{c}\text { Social } \\
\text { transfer }\end{array}$ & $\begin{array}{l}\text { Pensions } \\
\text { and } \\
\text { survivors' } \\
\text { benefits }\end{array}$ & $\begin{array}{c}\text { Inter- } \\
\text { household } \\
\text { transfer }\end{array}$ & $\begin{array}{c}\text { Other } \\
\text { Incomes }\end{array}$ & $\begin{array}{l}\text { Total } \\
\text { Income }\end{array}$ \\
\hline & & & & 2006 & & & & & \\
\hline $\mathrm{S}_{\mathrm{k}} \mathrm{G}_{\mathrm{k}} \mathrm{R}_{\mathrm{k}}$ & 0.0987 & 0.1385 & 0.0347 & 0.0532 & 0.0011 & 0.0335 & 0.0001 & 0.0259 & 0.3856 \\
\hline \multirow[t]{2}{*}{$\mathrm{S}_{\mathrm{k}}$} & 25.6 & 22.7 & 8.6 & 14.2 & 0.4 & 17.7 & 0.9 & 10 & 100 \\
\hline & & & & 2007 & & & & & \\
\hline $\mathrm{S}_{\mathrm{k}} \mathrm{G}_{\mathrm{k}} \mathrm{R}_{\mathrm{k}}$ & 0.1165 & 0.0911 & 0.0529 & 0.0729 & -0.0004 & 0.0344 & -0.0002 & 0.028 & 0.3952 \\
\hline \multirow[t]{2}{*}{$\mathrm{S}_{\mathrm{k}}$} & 26.5 & 17 & 11.9 & 15.8 & 0.4 & 17 & 0.9 & 10.6 & 100 \\
\hline & & & & 2008 & & & & & \\
\hline $\mathrm{S}_{\mathrm{k}} \mathrm{G}_{\mathrm{k}} \mathrm{R}_{\mathrm{k}}$ & 0.1036 & 0.1463 & 0.0261 & 0.063 & 0.0027 & 0.0242 & -0.001 & 0.0159 & 0.3808 \\
\hline \multirow[t]{2}{*}{$\mathrm{S}_{\mathrm{k}}$} & 24.2 & 24.8 & 7.2 & 15.3 & 0.8 & 17.9 & 1 & 8.8 & 100 \\
\hline & & & & 2009 & & & & & \\
\hline $\mathrm{S}_{\mathrm{k}} \mathrm{G}_{\mathrm{k}} \mathrm{R}_{\mathrm{k}}$ & 0.126 & 0.1318 & 0.0431 & 0.0721 & 0.0009 & 0.03 & 0.0004 & 0.0181 & 0.4224 \\
\hline \multirow[t]{2}{*}{$\mathrm{S}_{\mathrm{k}}$} & 25.2 & 21.1 & 10 & 15.2 & 0.6 & 18.3 & 1 & 8.6 & 100 \\
\hline & & & & 2010 & & & & & \\
\hline $\mathrm{S}_{\mathrm{k}} \mathrm{G}_{\mathrm{k}} \mathrm{R}_{\mathrm{k}}$ & 0.1493 & 0.1227 & 0.039 & 0.0526 & -0.0007 & 0.0237 & -0.0004 & 0.0174 & 0.4036 \\
\hline \multirow[t]{2}{*}{$\mathrm{S}_{\mathrm{k}}$} & 29.9 & 19.3 & 9 & 13.2 & 0.5 & 18.3 & 0.7 & 9.1 & 100 \\
\hline & & & & 2011 & & & & & \\
\hline $\mathrm{S}_{\mathrm{k}} \mathrm{G}_{\mathrm{k}} \mathrm{R}_{\mathrm{k}}$ & 0.1322 & 0.1499 & 0.0282 & 0.0591 & 0.0011 & 0.023 & 0.0001 & 0.0148 & 0.4082 \\
\hline \multirow[t]{2}{*}{$\mathrm{S}_{\mathrm{k}}$} & 27.7 & 23.4 & 7.4 & 13.3 & 0.7 & 18 & 0.9 & 8.6 & 100 \\
\hline & & & & 2012 & & & & & \\
\hline $\mathrm{S}_{\mathrm{k}} \mathrm{G}_{\mathrm{k}} \mathrm{R}_{\mathrm{k}}$ & 0.1413 & 0.1359 & 0.0362 & 0.0502 & 0.0002 & 0.0330 & -0.0003 & 0.0145 & 0.4111 \\
\hline \multirow[t]{2}{*}{$\mathrm{S}_{\mathrm{k}}$} & 28.48 & 20.66 & 7.99 & 13.13 & 0.18 & 20.39 & 0.7 & 8.47 & 100 \\
\hline & & & & 2013 & & & & & \\
\hline $\mathrm{S}_{\mathrm{k}} \mathrm{G}_{\mathrm{k}} \mathrm{R}_{\mathrm{k}}$ & 0.1647 & 0.1221 & 0.0271 & 0.0504 & 0.0002 & 0.0233 & -0.0004 & 0.0129 & 0.4003 \\
\hline \multirow[t]{2}{*}{$\mathrm{S}_{\mathrm{k}}$} & 33.14 & 18.96 & 6.87 & 13.04 & 0.25 & 19.92 & 0.59 & 7.23 & 100 \\
\hline & & & & 2014 & & & & & \\
\hline $\mathrm{S}_{\mathrm{k}} \mathrm{G}_{\mathrm{k}} \mathrm{R}_{\mathrm{k}}$ & 0.1655 & 0.1149 & 0.0202 & 0.0449 & 0.0003 & 0.0278 & 0.0003 & 0.0121 & 0.3860 \\
\hline $\mathrm{S}_{\mathrm{k}}$ & 33.76 & 18.37 & 6.25 & 12.46 & 0.36 & 20.8 & 0.81 & 7.19 & 100 \\
\hline
\end{tabular}

Source: Own calculations based on SILC Data

Table 4 shows the impact of a marginal percentage change in income source on total income inequality. Social transfer, pensions and survivors' benefits, inter-household transfers, and other income sources can be seen to have had a redistributive effect on inequality during the period of analysis. A one percentage change in total labor earnings, which had a redistributive effect in 2006, began to stimulate inequality in 2007. Furthermore, during the global financial crisis of 2008-2009, Gini elasticity $(\mathrm{Nj})$ increased gradually. After a decrease in 2011, the gradual increase continued. Gini elasticity values of entrepreneur income presents that, it has an inequality-increasing effect on inequality with a not as clear cut pattern through the years. 
The effect of one percentage change fluctuates over years with an increase in 2008 followed by a decrease in 2009 and increased from 2010 to 2014.

Table 4. Gini Elasticity $(\mathrm{Nj})$ and the Percent Change in Gini per 1 Percent Change in Income Source $(\%)$

\begin{tabular}{|c|c|c|c|c|c|c|c|c|c|}
\hline & & $\begin{array}{c}\text { Total } \\
\text { Labor } \\
\text { Earning }\end{array}$ & $\begin{array}{c}\text { Entrepreneur } \\
\text { income }\end{array}$ & $\begin{array}{l}\text { Financial } \\
\text { income }\end{array}$ & $\begin{array}{l}\text { Rental } \\
\text { Income }\end{array}$ & $\begin{array}{l}\text { Social } \\
\text { transfer }\end{array}$ & $\begin{array}{c}\text { Pensions and } \\
\text { survivors' } \\
\text { benefits }\end{array}$ & $\begin{array}{c}\text { Inter- } \\
\text { household } \\
\text { transfer }\end{array}$ & $\begin{array}{l}\text { Other } \\
\text { Incomes }\end{array}$ \\
\hline \multirow{2}{*}{2006} & $\mathrm{Nj}$ & 0.998 & 1.582 & 1.051 & 0.972 & 0.784 & 0.492 & 0.022 & 0.670 \\
\hline & $\%$ & -0.0004 & 0.1321 & 0.0044 & -0.004 & -0.0008 & -0.0898 & -0.0085 & -0.033 \\
\hline \multirow{2}{*}{2007} & $\mathrm{Nj}$ & 1.112 & 1.359 & 1.129 & 1.169 & -0.241 & 0.513 & -0.057 & 0.668 \\
\hline & $\%$ & 0.0297 & 0.0609 & 0.0153 & 0.0267 & -0.0053 & -0.0826 & -0.0093 & -0.0353 \\
\hline \multirow{2}{*}{2008} & $\mathrm{Nj}$ & 1.125 & 1.547 & 0.947 & 1.081 & 0.924 & 0.356 & -0.270 & 0.473 \\
\hline & $\%$ & 0.0302 & 0.1359 & -0.0039 & 0.0123 & -0.0006 & -0.1150 & -0.0123 & -0.0465 \\
\hline \multirow{2}{*}{2009} & $\mathrm{Nj}$ & 1.183 & 1.478 & 1.025 & 1.126 & 0.318 & 0.388 & 0.097 & 0.501 \\
\hline & $\%$ & 0.0461 & 0.1008 & 0.0025 & 0.0190 & -0.0043 & -0.1121 & -0.0093 & -0.0427 \\
\hline \multirow{2}{*}{2010} & $\mathrm{Nj}$ & 1.236 & 1.573 & 1.078 & 0.992 & -0.311 & 0.321 & -0.148 & 0.473 \\
\hline & $\%$ & 0.0706 & 0.1107 & 0.0070 & -0.0011 & -0.0068 & -0.1243 & -0.0080 & -0.0481 \\
\hline \multirow{2}{*}{2011} & $\mathrm{Nj}$ & 1.171 & 1.567 & 0.929 & 1.092 & 0.374 & 0.313 & 0.013 & 0.422 \\
\hline & $\%$ & 0.0471 & 0.1328 & -0.0053 & 0.0122 & -0.0044 & -0.1234 & -0.0092 & -0.0498 \\
\hline \multirow{2}{*}{2012} & $\mathrm{Nj}$ & 1.2071 & 1.6000 & 1.1010 & 0.9301 & 0.3364 & 0.3941 & -0.0959 & 0.4159 \\
\hline & $\%$ & 0.059 & 0.124 & 0.0081 & -0.0092 & -0.0012 & -0.1235 & -0.0077 & -0.0495 \\
\hline \multirow{2}{*}{2013} & $\mathrm{Nj}$ & 1.241 & 1.609 & 0.985 & 0.965 & 0.247 & 0.293 & -0.190 & 0.448 \\
\hline & $\%$ & 0.08 & 0.1154 & -0.001 & -0.0045 & -0.0019 & -0.1409 & -0.0071 & -0.0399 \\
\hline \multirow{2}{*}{2014} & $\mathrm{Nj}$ & 1.2698 & 1.6197 & 0.8358 & 0.9332 & 0.0029 & 0.0040 & 0.0013 & 0.0050 \\
\hline & $\%$ & 0.0911 & 0.1139 & -0.0103 & -0.0083 & -0.0027 & -0.1359 & -0.0072 & -0.0407 \\
\hline
\end{tabular}

Source: Own calculations based on SILC Data

On the other hand, a marginal increase in rental income has a re-distributive effect in 2006, 2010, 2012, 2013 and 2014. In 2008, its contribution to inequality decreased by 0.014 percentage point, then showed a slight increase in 2009. Social transfer, Pensions and survivors' benefits and Inter-household transfer has a re-distributive effect during the analysis period.

In order to assess the contribution of several variables to the level of earning inequality, the static decomposition of the Theil-T index was employed. "Education" related to human capital, "position in occupation," and "economic sector" related to physical capital accumulation were the chosen set of variables for explaining earning inequality among the economically active labor force in Turkey. As presented in equation 9 of the methodology section, the Theil $\mathrm{T}$ index is decomposed between and within the group components using the selected variables as subgroups. 
Table 5. Gross Contribution to the Explanation of Labor Earning Inequality (\%)

\begin{tabular}{lccccccccc}
\hline Variables & $\mathbf{2 0 0 6}$ & $\mathbf{2 0 0 7}$ & $\mathbf{2 0 0 8}$ & $\mathbf{2 0 0 9}$ & $\mathbf{2 0 1 0}$ & $\mathbf{2 0 1 1}$ & $\mathbf{2 0 1 2}$ & $\mathbf{2 0 1 3}$ & $\mathbf{2 0 1 4}$ \\
\hline Education & 14.6 & 14.7 & 15.9 & 18.1 & 20.1 & 18.2 & 19.7 & 20.2 & 19.1 \\
Pos. in Occupation & 19.4 & 19.3 & 19.0 & 16.7 & 15.3 & 16.2 & 17.7 & 17.1 & 16.2 \\
Economic Sector & 7.3 & 7.1 & 8.3 & 9.0 & 10.1 & 6.9 & 10.1 & 10.2 & 9.4 \\
\hline
\end{tabular}

Source: Own calculations based on SILC Data

Table 5 presents the gross contribution of each selected variable to income inequality, which is defined as the relative importance of between group component in overall income inequality.

From 2006 to 2008, position in occupation represents the relatively largest contribution to earning inequality in terms of its gross contribution. However, in 2009 education became the leading contributor to earning inequality. Education increased its gross contribution to earning inequality gradually from $14.6 \%$ to $20.1 \%$ between 2006 and 2010, and then decreased to $18.2 \%$ in 2011. From 2011 to 2013 , it gradually increased to 20.2, then dropped to 19.1 in 2014 . On the other hand, the gross contribution of position in occupation moved in the opposite direction from education during the analysis period, decreasing gradually from $19.4 \%$ to $15.3 \%$ between 2006 and 2010 , then slightly increasing to $17.7 \%$ in 2012 . It decreased to 16.2 in 2014 . The gross contribution of the economic sector to income inequality increased from $8.3 \%$ to $10.1 \%$ between 2008 and 2010, and then decreased to $6.9 \%$, which represents its lowest value over the period of analysis. From 2001 to 2013, it increased to 10.2, then decreased to 9.4 in 2014.

When $(\mathrm{Gj})$ is defined as the variable $\mathrm{j}$ 's gross contribution to overall earning inequality, $(\mathrm{Gjk})$ can be defined as the joint contribution of variable $\mathrm{k}$ and $\mathrm{j}$, which represents the inequality between the $\mathrm{K}$ and $\mathrm{J}$ groups related to the two variables. Finally, (Mkj) can be defined as the marginal contribution of variable $\mathrm{k}$ given variable $\mathrm{j}$, which can be calculated by subtracting the gross contribution of variable $\mathrm{j}$ from the joint contributions of $\mathrm{k}$ and $\mathrm{j}$ :

$$
M_{k j}=G_{j k}-G_{j}
$$

When $\mathrm{n}$ variables are included in the decomposition, marginal contributions from order 1 to order n-1 can be calculated (Psacharopoulos et al., 1997, 40).

To put it more generally, as explained by Acevedo and Salinas (2000), when an additional variable is included in a model that already contains certain variables, the marginal contribution of the added variable represents the difference between the gross contribution of these two models.

Table 6 presents the results with regard to the marginal contribution of education, position in occupation, and economic sector in explaining earning inequality. It can be seen that marginal contribution of education increased gradually from 2009 to 2013 after a slight decrease in 2008. In 2014, it showed a slight decreased. 
Table 6. Marginal Contribution to the Explanation of Labor Earning Inequality (\%)

\begin{tabular}{lccccccccc}
\hline Variables & $\mathbf{2 0 0 6}$ & $\mathbf{2 0 0 7}$ & $\mathbf{2 0 0 8}$ & $\mathbf{2 0 0 9}$ & $\mathbf{2 0 1 0}$ & $\mathbf{2 0 1 1}$ & $\mathbf{2 0 1 2}$ & $\mathbf{2 0 1 3}$ & $\mathbf{2 0 1 4}$ \\
\hline Education & 9.7 & 10.5 & 10.1 & 11.0 & 11.8 & 12.4 & 12.6 & 12.7 & 12.4 \\
Pos. in Occupation & 17.2 & 18.8 & 17.7 & 15.6 & 13.9 & 14.9 & 16.8 & 16.2 & 15.9 \\
Economic Sector & 5.6 & 6.5 & 7.0 & 7.1 & 6.0 & 5.8 & 7.1 & 6.9 & 6.2 \\
\hline
\end{tabular}

Source: Own calculations based on SILC Data

However, position in occupation decreased steadily from 2007 to 2010 followed by a $2.9 \%$ increase during 2011-2012 period. Then it steadily decreased to 15.9\% from 2012 to 2014 . The contribution of economic sector increased between 2006 and 2009, yet decreased in 2010 and 2011. After a slight increase in 2012, it decreased to $6.2 \%$ in 2014. The results of the static decomposition analysis show that, while the significance of education has increased over time in relation to income inequality, position in occupation has decreased in terms of both its marginal and gross contribution to earning inequality. Economic sector appeared to be relatively less important.

\section{Conclusion}

The analysis showed that the downward trend in income inequality between 2006 and 2014 has been distorted by the 2008-2009 global financial crisis. The slight income transfer to both bottom $10 \%$ and middle $40 \%$ income classes from top $10 \%$ and middle high $30 \%$. The results of the Lorenz curve analysis also show that the low, middle, and middle-high income groups were not only hit relatively lately by the financial crisis, but that they also received higher income shares than their pre-crisis levels in 2014. On the other hand, the richest stratum could not maintain its pre-crisis income share by the end of the crisis period.

Results from the Gini decomposition by income source indicate that total labor earnings and entrepreneur income which were the most significant income components by their share in total income, were also the most significant income components that contributed to income inequality. Over the period of 2008-2009 financial crisis, contribution of total labor earnings and entrepreneur income to inequality moved in the opposite direction from each other. From 2008 to 2010, the contribution of total labor earnings to inequality increased while the contribution of entrepreneur income to inequality decreased. Social transfers which contributed negatively to income inequality in 2007 and 2010, had a slight positive contribution to inequality in 2008 and 2009. Examining the effect of one percentage change in income source to total inequality, i.e Gini elasticity, it is found that, social transfer, pensions and survivors' benefits and inter-household transfers had a redistributive effect on inequality. Decomposition of Theil T analysis showed that during the 2008-2009 global financial crisis, while the importance of the education increased, position in occupation lost its significance in terms of both their gross and marginal contribution to earning inequality. 


\section{References}

Acevedo, G. L., \& Salinas, A. (2000). How Mexico's financial crisis affected income distribution (Vol. 2406). World Bank Publications. http://EconPapers.repec.org/RePEc:wbk:wbrwps:2406

Agnello, L., \& Sousa, R. M. (2014). How Does Fiscal Consolidation Impact on Income Inequality?. Review of Income and Wealth, 60, 702-726. https://doi.org/10.1111/roiw.12004

Araar, A. (2006). On the Decomposition of the Gini Coefficient: an Exact Approach, with an Illustration Using Cameroonian Data, Cahiers de recherche, CIRPEE, http://EconPapers.repec.org/RePEc:lvl:lacicr:0602

Araar, A., \& Duclos J. Y. (2008). An Algorithm for Computing the Shapley Value. PEP and CIRPEETech. Note: Novembre 2008, http://132.203.59.36/DAD/pdf_files/shap_dec_aj.pdf

Arieff, A., Weiss M. A., \& Vivian C. J. (2011). Global Economic Crisis: Impact on Sub-Saharan Africa and Global Policy Responses. Current Politics and Economics of Africa, 4(1), 21.

Arslan, E. B. (2014). An Analysis Of Wage, Earnings and Income Inequality in Turkey (Unpublished master's thesis). TOBB University of Economics and Technology, ANKARA.

Ball, L., Furceri. D., Leigh. D., \& Loungani, P. (2003). The distributional effects of fiscal consolidation. IMF working paper No. 13/151 (Washington, D.C.).

Baslevent, C. (2010). Recent Trends in Factor Contributions to Household Income Inequality in Turkey. http://dx.doi.org/10.2139/ssrn.1687066

Baslevent, C. (2014). Social Transfers and Income Inequality in Turkey: How Informative Is the Survey of Income and Living Conditions?. Ekonomi-tek-International Economics Journal, 3(3), 23-42.

Brandolini, A., Jenkins, S. P., Micklewright, J., \& Nolan, B. (Eds.). (2013). The Great Recession and the Distribution of Household Income (pp. 130-52). Oxford: Oxford University Press.

Brinkman, Henk-Jan, de Pee, S., Sanogo, I., Subran, L., \& Bloem, M.W. (2010). High food prices and the global financial crisis have reduced access to nutritious food and worsened nutritional status and health. The Journal of nutrition, 140(1), 153-161.

Camargo, J. M., \& Neri, M. C. (2002). Distributive effects of Brazilian structural reforms. En: Brazil in the 1990s: an economy in transition-London: Palgrave/St. Antony's College, 2002-p. 262-312.

Çetin, B. I., \& Güz, M. (2013). Türkiye'de 2002-2009 Yılları Arasında Gelir Bileşenleri ve Gelir Eşitsizliği Analizi, Çalışma ve Toplum, 1, 253-292. 
Cord, L., Barriga - Cabanillas, O., Lucchetti, L., Rodríguez - Castelán, C., Sousa, L. D., \& Valderrama, D. (2017). Inequality stagnation in Latin America in the aftermath of the global financial crisis. Review of Development Economics, 21(1), 157-181. https://doi.org/10.1111/rode.12260

Cutler, D. M., \& Katz, L. F. (1992). Rising Inequality? Changes in the Distribution of Income and Consumption in the 1980s (No. w3964). National Bureau of Economic Research. https://doi.org/10.3386/w3964

De Beer, P. (2012). The Impact of the Crisis on Earnings and Income Distribution in the EU. European Trade Union Institute.

Dufour, M., \& Orhangazi, Ö. (2014). Capitalism, crisis, and class: The United States economy after the 2008 financial crisis. Review of Radical Political Economics, 46(4), 461-472. https://doi.org/10.1177/0486613414537981

Elveren, A. Y., \& Galbraith, J. K. (2009). Pay inequality in Turkey in the neo-liberal era, 1980-2001. The European Journal of Comparative Economics, 6(2), 177.

Fei, J. C., Ranis, G., \& Kuo, S. W. (1978). Growth and the family distribution of income by factor components. The Quarterly Journal of Economics, 92(1), 17-53.

Jovanovic, B. (2014). Inflation and the rich after the global financial crisis (No. 613). LIS Working Paper Series.

Leibbrandt, M., Woolard, C., \& Woolard, I. (2000). The contribution of income components to income inequality in the rural former homelands of South Africa: a decomposable Gini analysis. Journal of African Economies, 9(1), 79-99. https://doi.org/10.1093/jae/9.1.79

Lerman, R. I., \& Yitzhaki, S. (1985). Income inequality effects by income source: a new approach and applications to the United States. The review of economics and statistics, 151-156.

Mishel L., \& Gee K. (2012). Why aren't workers benefiting from labor productivity growth in the US. International Productivity Monitor, 23, 31-43.

Mishel, L. (2012). The wedges between productivity and median compensation growth. Issue Brief, 330, 1-7.

Otker-Robe, I., \& Podpiera, A. M. (2013). The social impact of financial crises: evidence from the global financial crisis. World bank policy research working paper 6703.

Podder, N., \& Chatterjee, S. (2002). Sharing the national cake in post reform New Zealand: income inequality trends in terms of income sources. Journal of Public Economics, 86(1), 1-27.

Psacharopoulos G., Morley, S., Fiszbein, A., Lee, H., \& Wood, B. (1993). Poverty and Income Distribution in Latin America: The Story of the 1980s. Latin America and the CaribbeanTechnical Department Regional Studies Program, Report No. 27. Washington, 
DC, United States: World Bank.

Pyatt, G., Chen, C. N., \& Fei, J. (1980). The distribution of income by factor components. The quarterly journal of economics, 95(3), 451-473.

Ramos, L. (1990). The Distribution of Earnings in Brazil: 1976-1985. (Doctoral Dissertation). University of California, Berkeley.

Rao, V.M. (1969). Two Decompositions of Concentration Ratio. Journal of the Royal Statistical Society, Series A(132), 418-425.

Saez, E. (2009). Striking it richer: The evolution of top incomes in the United States (update with 2007 estimates). Berkeley: University of California, Department of Economics.

Şenergin, Ö. (2010). Eğitim Düzeyi Farklılıklarının Gelir Dă̆llımına Etkisi. (Unpublished master's thesis). Balıkesir Üniversitesi Sosyal Bilimler Fakültesi, Balıkesir.

Shorrocks, A. F. (1982). Inequality Decomposition by Factor Components. Econometrica, 50, 193-211.

Silber, J. (1993). Income Decomposition by Income Source: A Note. Review of Economics and Statistics, LXXV, 545-547.

Silber, J., \& Ozmucur, S. (2000). Decomposition of Income Inequality: Evidence from Turkey. Topics in Middle Eastern and North African Economies, 2. Retrieved from http://www.luc.edu/orgs/meea/volume2/ozmucur2.doc

Stark, O., Taylor, J. E., \& Yitzhaki, S. (1986). Remittances and inequality. The economic journal, 96(383), 722-740.

Taştan, H., \& Akar, M. (2013). Türkiye İmalat Sanayiinde Bölgesel ve Sketorel Ücret Eşitsizliğii. İktisat Fakültesi Mecmuası, 63(1), 17-49.

Woo, J., Bova, M. E., Kinda, M. T., \& Zhang, M. Y. S. (2013). Distributional consequences of fiscal consolidation and the role of fiscal policy: What do the data say? (No. 13-195). International Monetary Fund.

\section{Notes}

Note 1. Cumulative distribution and covariance are calculated by using the household weights.

Note 2. $R_{k}$ is the correlation coefficient between $Y$ and $Y_{k}$, i.e. $R_{k}=\frac{\operatorname{cov}\left[Y_{k} F(Y)\right]}{\operatorname{cov}\left[Y_{k}, F\left(Y_{k}\right)\right]}$

Note 3. National Equivalence Scale was calculated by Turkish Statistical Institute based the following parameter equivalence scale form by using Household Budget Survey of 2002:

$\mathrm{E}=(\mathrm{A}+\alpha \mathrm{C})^{\theta}, \quad 0 \leq \theta \leq 1$ and $0<\alpha \leq 1$

where $\mathrm{A}$ and $\mathrm{C}$ are the number of adults and children in the household respectively, $\alpha$ is the 
weighting parameter for number of children relative to number of adults, and $\Theta$ is the parameter of economies of scale. Turkish Statistical Institute calculated these parameters as $\alpha$ $=0.6$ and $\Theta=0.9$.

\section{Copyright Disclaimer}

Copyright for this article is retained by the author(s), with first publication rights granted to the journal.

This is an open-access article distributed under the terms and conditions of the Creative Commons Attribution license (http://creativecommons.org/licenses/by/3.0/). 